\title{
Effect of Graded Levels of Dietary Emamectin Benzoate on Immunity, Enzyme Activity, and Withdrawal Period in Labeo rohita Juveniles (Hamilton, 1822)
}

\author{
Pushpa Choudhary, ${ }^{1}$ Priyabrat Swain $\mathbb{D}^{1},{ }^{1}$ Rakesh Das $\left(\mathbb{D},{ }^{1}\right.$ Satya Narayan Sahoo $\left(\mathbb{D},{ }^{1}\right.$ \\ Krushna Chandra Das, ${ }^{1}$ Prasanna Kumar Patil, ${ }^{2}$ and Sudhansu Sekhar Mishra ${ }^{1}$ \\ ${ }^{1}$ ICAR-Central Institute of Freshwater Aquaculture (CIFA), Kausalyaganga, Odisha, India \\ ${ }^{2}$ ICAR-Central Brackish Water Aquaculture (CIBA), Chennai, Tamil Nadu, India
}

Correspondence should be addressed to Priyabrat Swain; pswainy2k@yahoo.co.in

Received 26 November 2021; Accepted 10 January 2022; Published 18 February 2022

Academic Editor: Ayşegül Kubilay

Copyright (c) 2022 Pushpa Choudhary et al. This is an open access article distributed under the Creative Commons Attribution License, which permits unrestricted use, distribution, and reproduction in any medium, provided the original work is properly cited.

\begin{abstract}
This study was conducted to evaluate the effect of dietary emamectin benzoate (EB) levels on immune responses, serum enzyme activities, and retention of EB in muscle tissue to establish the withdrawal period in rohu, Labeo rohita juveniles (avg. wt. $18 \pm 0.11$ g). To ascertain this, 450 healthy L. rohita juveniles were fed with EB in graded doses viz., at 50 (1x), 125 (2.5x), 250 (5x), and 375 (7.5x) $\mu \mathrm{g} \mathrm{kg}^{-1}$ of fish biomass day ${ }^{-1}$, respectively, in triplicate for 21 days through a basal feed. Upon completion of 21 days, the same experimental fish were fed with basal feed (without EB) for another 14 days to measure the retention of EB in the muscle tissue. Each 7-day interval, five fish were randomly sampled. The results showed that respiratory burst activity, myeloperoxidase activity, bacterial haemagglutination, and haemolysis activities were improved significantly $(p<0.05)$ in $1 \mathrm{x}$ and $2.5 \mathrm{x}$ dose fed group from $7^{\text {th }}$ day onwards until $14^{\text {th }}$ day. Few selected enzyme activities viz., LDH and ALP were found to be significantly $(p<0.05)$ high in the fish fed with EB at $5 \mathrm{x}$ and $7.5 \mathrm{x}$ dose compared to $1 \mathrm{x}$. The LC-MS/MS study of the experimental fish discloses that EB was retained in muscle tissue at a dose-dependent manner and significantly $(p<0.05)$ lowest level $(0.341 \pm 0.03 \mathrm{ppb})$ was retained in the fish fed with $1 \mathrm{x}$ dose of EB. Hence, $1 \mathrm{x}$ dose of EB may be adhered to treat L. rohita juveniles through feed with 14 days of withdrawal period.
\end{abstract}

\section{Introduction}

Parasitic diseases are increasingly recognized as a possible restriction for sustainable freshwater aquaculture, and their control is always extremely challenging. The ectoparasitic infestation in freshwater farmed fishes causes a significant loss to the farmers in the aquaculture sector, thereby resulting in substantial economic losses. Few common parasites viz., Argulus sp., Ichthyophthirius sp., Trichodina sp., Dactylogyrus sp., and Lernaea sp., are mainly found in Indian freshwater carp culture system [1, 2]. Furthermore, few selected families of parasites like Argulidae, Caligidae, Lernaeidae, and Cymothoidae are always a major concern in aquaculture worldwide due to repeated occurence and significant economic loss cater by them [3]. Recently, FDA has approved emamectin benzoate (EB) in aquaculture exclusively through feed treatment for controlling several ectoparasitic infestations. However, there is no information on the effect of the EB on immunity and important enzyme activities related to the health parameters of treated fish ( $L$. rohita) during and post administration of EB through the basal feed. To answer such query, the present investigation has been designed and executed at tropical climate (avg. temp. $\sim 30^{\circ} \mathrm{C}$ ) with minimum and maximum concentrations or dose levels of EB (1x-7.5x) through the feed with 14 days of withdrawal strategy. EB was originally used for controlling pests in edible plant crops, but at a later date, it was found to be an effective antiparasitic drug against sea lice treatment in farmed Atlantic salmon in the UK, Norway, and Canada [4]. EB acts by releasing neurotransmitter inhibitory substances 
and subsequently causing the paralysis followed by death of insects upon ingestion [5]. It is a mixture of two chemicals with a similar structure mixed with minimum of $90 \% 4^{\prime \prime}$ -epimethylamino- $4^{\prime \prime}$-deoxyavermectin B1a and a maximum of $10 \% 4^{\prime \prime}$-epi-methylamino- $4^{\prime \prime}$-deoxyaverrnectin Blb benzoate [6]. The benzoate salt of emamectin has greater water solubility and low toxicity and has better thermal stability than hydrochloride salt and has broader insecticidal spectrum than ivermectin. Over the years, parasitic diseases causing significant economic loss to the freshwater fish farmers and to control such loss the availability of safe or approved antiparasitic drug is always an important and need-based concern. In addition, the control of any infectious diseases (bacteria, parasitic, or viral) in the aquaculture system depends on decent management practices, along with the use of few or selected approved, safe, and commercially available drugs and vaccines [7]. Hence, studying the possible health impact (mainly nonspecific immunity and enzymatic indices) during and postfeeding of EB is a well-verged topic to carry out the research and need of the hour before it is adequately recommended for wider application. Furthermore, the withdrawal period is also playing an important role, and till date, few developed countries already made their standard withdrawal protocol (drug specific) for selected aquaculture drugs. Therefore, to establish the withdrawal period for such antiparasitic drug by conducting tissue level retention study will definitely help to make the standard withdrawal period for sustainable carp aquaculture production and to up-keep the better health of farmed rohu, Labeo rohita or treated fish.

Rohu, Labeo rohita is one of the highest preferred freshwater fish in South Asian countries, viz., Bangladesh, Nepal, Pakistan, and India. Moreover, in Indian freshwater carp culture system, L. rohita is always susceptible to a series of ectoparasite infestation during the grow out culture system (juveniles to preadult to adult stage/marketable size) in ponds or tanks or reservoir. Therefore, systematic evaluation of EB (antiparasitic drug) on immunity, enzyme activities, and deposition of EB in the fish muscle after administration through the feed is well approached.

\section{Material and Methods}

2.1. Preparation of Experimental Fish. Healthy L. rohita juveniles (avg. wt. $18 \pm 0.11 \mathrm{~g}$ ) with no record of parasitic or bacterial infections were procured from Odisha Pisciculture Development Corporation Farm, Kausalyaganga, Odisha, to carry out the present investigation. Four hundred and fifty healthy fish were procured and stocked in FRP (fiber-reinforced plastic) tank (5001) with continuous aeration support at wet-lab facility of ICAR-CIFA, Odisha, for 15 days as acclimatization period. During that time, fish were fed with only the basal feed (control diet with $\sim 30 \%$ crude protein level), and water parameters were maintained in optimal ranges.

2.2. Experimental Condition. Feeding experiment was carried out at wet-lab facility of FHMD, ICAR-CIFA, Odisha, by continuous aeration support and the temperature of the tank water was maintained at $28 \pm 0.5^{\circ} \mathrm{C}$ throughout the experimental duration. Thirty fish were stocked in each EB-treated tanks (1x, T1; 2.5x, T2; 5x, T3; and 7.5x, T4) and control ( $\mathrm{C}$; without $\mathrm{EB})$ with triplicates. The water quality parameters were measured following standard methods [8]. The recorded water parameters were found to be in optimal ranges during the entire experimental period. The experimental fish were fed twice (half meal at a time) a day (at 9:00 and 17:00 h) at 3\% average body weight per day basis. EB (1x-7.5x) incorporated diet fed for 21days as per the given graded level and followed by 14days of withdrawal period (while EB was not administered, only the basal feed was continued).

2.3. Design of Experiment. The feeding experiment was conducted in triplicates with completely randomized design (CRD). The inclusion of emamectin benzoate (PESTANAL ${ }^{\circledR}$, analytical standard, Product Number: 31733; PESTANAL is a registered trademark of Sigma-Aldrich International $\mathrm{GmbH}$ ) was added as following doses to the basal feed and designated as

(i) (T0): control: only basal feed without EB

(ii) (T1): $1 \mathrm{x}$ concentration of $\mathrm{EB}$ at $50 \mu \mathrm{g} \mathrm{kg}^{-1}$ of fish biomass per day

(iii) (T2): $2.5 \mathrm{x}$ concentration of EB at $125 \mu \mathrm{g} \mathrm{kg}^{-1}$ of fish biomass per day

(iv) (T3): $5 \mathrm{x}$ concentration of $\mathrm{EB}$ at $250 \mu \mathrm{g} \mathrm{kg}^{-1}$ of fish biomass per day

(v) (T4): $7.5 \mathrm{x}$ concentration of EB at $375 \mu \mathrm{g} \mathrm{kg}^{-1}$ of fish biomass per day

The amount of EB prerequisite was calculated as based on $3 \%$ feed per $\mathrm{kg} \mathrm{ABW} \mathrm{day}^{-1}$ (fish biomass). Hence, to determine the availability of EB in the medicated feed, the final amount of EB was added to the per $\mathrm{kg}$ of basal feed at $1.67 \mathrm{mg}(1 \mathrm{x}), 4.17 \mathrm{mg}(2.5 \mathrm{x}), 8.33 \mathrm{mg}(5 \mathrm{x})$, and $12.5 \mathrm{mg}$ $(7.5 x)$, respectively.

2.4. Medicated Feed Preparation. EB-incorporated (medicated) feed was prepared at ICAR-CIFA, Kausalyaganga, Odisha, by using locally available feed ingredients (Table 1) and keeping all the necessary nutritional requirements as per the need of experimental fish. Furthermore, the prepared mediciated feed found to be contains $296 \mathrm{~g} \mathrm{~kg}^{-1}$ of crude protein which is appropriate for the experimental species at juvenile stage. Initially, all the feed ingredients were cooked (autoclaved) once the temperature of the dough came down to $\sim 37^{\circ} \mathrm{C}$ commercially available vitamin and mineral mixture was added along with the calculated amount of EB. Carboxy methyl cellulose (CMC) was used as a binder. The final dough was pressed through a hand pelletizer to get uniform-sized pellets $(2 \mathrm{~mm})$, and pellets were dried at room temperature $\left(\sim 30^{\circ} \mathrm{C}\right)$ for $48 \mathrm{~h}$. At the end, the pelleted feed was packed in airtight bags and kept at $4^{\circ} \mathrm{C}$ for further use. 
TABLE 1: Composition of medicated feed and control feed $\left(\mathrm{g} \mathrm{kg}^{-1}\right)$.

\begin{tabular}{|c|c|c|c|c|c|}
\hline Feed ingredients (g) & Control & $\begin{array}{c}\mathrm{T} 1 \\
(1 \mathrm{x}, 50 \mu \mathrm{g} / \mathrm{kg})\end{array}$ & $\begin{array}{c}\mathrm{T} 2 \\
(2.5 \mathrm{x}, 125 \mu \mathrm{g} / \mathrm{kg})\end{array}$ & $\begin{array}{c}\mathrm{T} 3 \\
(5 \mathrm{x}, 250 \mu \mathrm{g} / \mathrm{kg})\end{array}$ & $\begin{array}{c}\mathrm{T} 4 \\
(7.5 \mathrm{x}, 375 \mu \mathrm{g} / \mathrm{kg})\end{array}$ \\
\hline Fish meal & 50 & 50 & 50 & 50 & 50 \\
\hline Soya meal & 280 & 280 & 280 & 280 & 280 \\
\hline GNOC & 260 & 260 & 260 & 260 & 260 \\
\hline Rice bran & 200 & 200 & 200 & 200 & 200 \\
\hline Corn flour & 150 & 150 & 150 & 150 & 150 \\
\hline Oil mix (ml) & 40 & 40 & 40 & 40 & 40 \\
\hline Vitamin and mineral mixture & 20 & 20 & 20 & 20 & 20 \\
\hline Emamectin benzoate (EB) & 0 & $0.00167 \mathrm{~g}(1.67 \mathrm{mg})$ & $0.00417 \mathrm{~g}(4.17 \mathrm{mg})$ & $0.00833 \mathrm{~g}(8.33 \mathrm{mg})$ & $0.0125 \mathrm{~g}(12.5 \mathrm{mg})$ \\
\hline
\end{tabular}

Composition of vitamin-mineral premix (PREEMIX PLUS) (quantity/2.5 kg): vitamin A, $5500000 \mathrm{IU}$; vitamin D3, $1100000 \mathrm{IU}$; vitamin B2, $2000 \mathrm{mg}$; vitamin E $750 \mathrm{mg}$; vitamin K, $1000 \mathrm{mg}$; vitamin B6, $1000 \mathrm{mg}$; vitamin B12, $6 \mathrm{mcg}$; calcium pantothenate, $2500 \mathrm{mg}$; nicotinamide, $10 \mathrm{~g}$; choline chloride, $150 \mathrm{~g}$; Mn, 27,000 mg; I, 1000 mg; FE 7500 mg; Zn, 5000 mg; Cu, 2000 mg; Co, 450 mg; L-lysine, 10 g; DL-methionine, 10 g; selenium, 50 ppm; satwari, 2500 mg.

2.5. Sampling of Experimental Fish. To determine the growth of fish, at each sampling day $\left(7^{\text {th }}, 14^{\text {th }}, 21^{\text {st }}\right.$, and $35^{\text {th }}$ day), five fish were randomly collected from each tank, weighed (Mettler Toledo), and followed by anaesthetized with clove oil at $50 \mu \mathrm{l} \mathrm{liter}{ }^{-1}$ of water; then, blood was drawn from the caudal vein using a $2.0 \mathrm{ml}$ hypodermal syringe. Approximately $500-600 \mu \mathrm{l}$ of blood was drawn from each fish and was immediately transferred into two vials, one coated with thin layer anticoagulant i.e., EDTA, and the other one without it. Vials having anticoagulants were shaken gently to prevent hemolysis. Serum separation was done by incubating the vials in slanting position for about $1 \mathrm{hr}$, followed by centrifuging them at $3000 \mathrm{~g}$ for $15 \mathrm{~min}$ at $4^{\circ} \mathrm{C}$ and taken out using a micropipette and stored at $-20^{\circ} \mathrm{C}$ until further use. For liquid chromatography-mass spectrometry/mass spectrometry (LC-MS/MS) study, muscle tissues were collected from the dorsal part of the treated (EB-fed) fish and immediately stored at $-80^{\circ} \mathrm{C}$ until further use.

\subsection{Estimation of Immune Parameters}

2.6.1. Myeloperoxidase Activity. Serum myeloperoxidase activity was determined as per [9] method. In brief, $15 \mu \mathrm{l}$ of fish serum collected from experimental fish and control fish was diluted in $135 \mu \mathrm{l}$ of Hank's balanced salt solution (Ca2+, $\mathrm{Mg} 2+$ free), followed by the addition of $50 \mu \mathrm{l}$ of $20 \mathrm{mM}$ of $3,3^{\prime}, 5,5^{\prime}$-tetra methyl benzidine and $5 \mathrm{mM}$ of hydrogen peroxide to it. Afterwards, the above mixture was incubated for two minutes at room temperature and ending of the reaction was done by addition of $4 \mathrm{M}$ sulphuric acid into it. Finally, the optical density was measured by UV-VIS Spectrophotometer (Thermo Spectronic, UK) at $450 \mathrm{~nm}$.

2.6.2. Respiratory Burst Activity. The respiratory burst activity which ultimately measures the reduction in nitroblue tetrazolium (NBT) by intracellular superoxide radicals. The following steps were followed to attain this; $50 \mu \mathrm{l}$ of heparinized blood was mixed and incubated for 30 minutes at $25^{\circ} \mathrm{C}$ with $50 \mu \mathrm{l}$ of $0.2 \%$ NBT (Sigma, USA) solution. Afterwards, $50 \mu \mathrm{l}$ of the above mixture was taken and added to $1 \mathrm{ml}$ of $\mathrm{N}, \mathrm{N}$, diethylmethyl formamide (Qualigens, India). Then, it was centrifuged at $6000 \mathrm{~g}$ for 5 minutes. The optical density of the supernatant was read at $540 \mathrm{~nm}$ using the UV-VIS Spectrophotometer (Thermo Spectronic, UK) [10].

2.6.3. Lysozyme Assay. To carry out lysozyme activity assay, a lyophilized Micrococcus lysodeikticus (Sigma-Aldrich, USA) was used as described by Ellis [11]. In brief, $130 \mu \mathrm{l}$ of freshly prepared $M$. lysodeikticus solution which contains $0.6 \mathrm{mg} \mathrm{ml}^{-1}$ (in $0.02 \mathrm{M}$ sodium citrate buffer) was added to a mixture comprising of $10 \mu \mathrm{l}$ fish serum and $10 \mu \mathrm{l}$ of $0.02 \mathrm{M}$ sodium citrate buffer. The initial optical density was immediately read at $450 \mathrm{~nm}$ after adding bacterial solution into it. Further, the OD of the samples was read at the same wavelength $(450 \mathrm{~nm})$ postincubation for $1 \mathrm{hr}$ at $24^{\circ} \mathrm{C}$. Simultaneously, a standard curve was prepared using a mixture of $20 \mu \mathrm{l}$ working standard and $130 \mu \mathrm{l}$ of $M$. lysodeikticus solution in separate. Finally, lysozyme activity was expressed in units $\mathrm{ml}^{-1}$ where one unit is defined as the decrease in absorbance of $0.001 \mathrm{~min}^{-1}$.

2.6.4. Bacterial Agglutination Activity. Bacterial agglutination test was carried out as per [12]. In brief, twofold serially diluted fish serum samples were taken at $25 \mu \mathrm{l}$ with an equal volume of normal salt solution in each well. After that, $25 \mu \mathrm{l}$ of formalin-killed Aeromonas hydrophila $\left(10^{7}\right.$ cells $\left.\mathrm{ml}^{-1}\right)$ suspension was added next to each of the wells followed by incubation of microtitre plate for overnight at $37^{\circ} \mathrm{C}$. At the end, the final titre was calculated as the reciprocal of the highest dilution of serum showing complete agglutination of the bacterial cells.

2.6.5. Hemagglutination Activity. The hemagglutination activity was carried out following Blazer et al. [13]. In brief, ' $U$ '-shaped microtiter plates were loaded with twofold serial dilution of $25 \mu \mathrm{l}$ fish serum samples which has been inactivated by keeping at $45^{\circ} \mathrm{C}$ for 30 mins followed by using an equal volume of NSS. Then, $25 \mu \mathrm{l}$ of freshly prepared $1 \%$ New Zealand white rabbit red blood cell (RBC) suspension was added to all the wells followed by incubation of plate at room temperature $\left(28-30^{\circ} \mathrm{C}\right)$ for $2 \mathrm{~h}$ or at $4^{\circ} \mathrm{C}$ overnight. Finally, the titre was calculated as the reciprocal of the highest dilution of serum showing complete agglutination of RBC. 
2.6.6. Haemolytic Activity. The haemolytic activity assay of serum sample was as per Blazer et al. [13]. In brief, collected fish sera were subjected to the protocol used for determining the HA titre. In this case, the plates were incubated at room temperature overnight. At the end, the titre was expressed as the reciprocal of the highest dilution of serum showing complete haemolysis of rabbit RBCs.

\subsection{Estimation of Enzyme Activity}

2.7.1. Alkaline Phosphatase Activity Assay. The alkaline phosphatase activity (ALP) in the fish serum for the entire sample including treated and control was assessed using the ready-to-use kit-alkaline phosphatase activity kit (Bio Vision, USA) - using the manufacturer's instructions. Here, analysis was confirmed by seeing the formation of dephosphorylated by alkaline phosphatase which turns yellow $(\lambda \max =405 \mathrm{~nm})$. P-nitrophenyl phosphate $(\mathrm{pNPP})$ was being used as a phosphatase substrate.

2.7.2. Lactate Dehydrogenase Activity Assay. The lactate dehydrogenase (LDH) activities in the fish serum for the treated and control samples were analysed by following the instruction of a ready-to-use kit (Sigma-Aldrich, USA).

2.8. LC-MS/MS Analysis of Fish Muscle (Edible) Tissue. EB residue in different treatment groups $(1 \mathrm{x}-7.5 \mathrm{x})$ of fish tissue (muscle) was quantified by liquid chromatographymass spectrometry/mass spectrometry (LC-MS/MS) according to Ananda Raja et al. [14] with slight modification. Briefly, the desired tissue samples were weighted and homogenized; then, $5 \mathrm{~g}$ of homogenate was transferred to a $50 \mathrm{ml}$ centrifuge tube and was mixed with $20 \mathrm{ml}$ of acetone and centrifuged at $7500 \mathrm{~g}$ for 10 minutes. The supernatant was transferred to a $100 \mathrm{ml}$ round bottom flask, and the sample was reextracted with $10 \mathrm{ml}$ of acetone. Supernatants were combined, and acetone from them was removed by using rotary evaporator, and the aqueous solution obtained was then loaded on to the column and the aqueous eluent; solvent was discarded. The elute was collected and dried in rotary evaporator which was further dissolved in $2 \mathrm{ml}$ of acetonitrile including 1\% acetic acid. Five microliters of the final solution were injected into the LC-MS/MS system, and the quantity of the EB was determined at the retention time of 5 minutes.

2.9. Statistical Analysis. All the data were checked for homogeneity of the variances by using Levene's test [15]. In addition, to determine the effect of EB in experimental fish by measuring the immunity, enzyme activity, and tissue level retention, a one-way analysis of variance (ANOVA) have been performed, using Duncan's multiple range test (DMRT) according to Steel and Torrie [16] by using SPSS program (version 22, IBM). Differences between means were compared in all statistical tests used, and $p<0.05$ was considered as significantly different. All the results presented as mean \pm standard error (SE).

\section{Results}

3.1. Growth and Immunity. To assess the impact of $\mathrm{EB}$ on growth of fish during the feeding trial (1x-7.5x dose of EB), all the experimental fish were periodically weighted on each sampling days $\left(7^{\text {th }}, 14^{\text {th }}\right.$, and $21^{\text {st }}$ days). The final growth of fish had no significant difference $(p>0.05)$ among the treated and control group fish (without EB). The nonspecific immune parameters such as myeloperoxidase activity, respiratory burst activity, lysozyme activity, haemagglutination, and bacterial agglutination titre were significantly varied $(p<0.05)$ with treated fish compared with the control. The results were presented in Figures 15 . The respiratory burst activity in the blood of the treated and control fish was significantly higher in $1 \mathrm{x}$ and $2.5 \mathrm{x}$ than control fish and lowered in $5 \mathrm{x}$ concentration and $7.5 \mathrm{x}$ concentration $(p<0.05)$ until the $21^{\text {st }}$ day. The myeloperoxidase activity of the treated and control fish was significantly diverse in all the groups during the feeding trial. It was higher $(p<0.05)$ in $1 \mathrm{x}$ and $2.5 \mathrm{x}$ EB-fed treatment groups and lower in $5 \mathrm{x}$ and 7.5x EB fed groups. The haemagglutination activity and the haemolysis activity was found to be high in all the fish fed with $\mathrm{EB}$ ( $1 \mathrm{x}$ and $2.5 \mathrm{x}$ concentrations) on day $7^{\text {th }}$ onward, but gradually reduced after withdrawal of the EB. The lysozyme activity was like the control, and the bacterial agglutination activity was found to be unchanged.

3.2. Enzymatic Responses. The enzyme activities have been performed in serum viz., lactate dehydrogenase activity and alkaline phosphatase activity. The result of the study showed that significant increase $(p<0.05)$ in the treated fish those who have received $5 \mathrm{x}$ and $7.5 \mathrm{x}$ concentrations of $\mathrm{EB}$ (presented in Figures 6 and 7). Additionally, withdrawal of EB results to minimization of the value of such enzymes in case of fish fed with $<2.5 \mathrm{x}$ dose. The LDH and ALP were found to be significantly unchanged in fish fed with $5 \mathrm{x}$ and $7.5 \mathrm{x}$ dose of EB compared to the fish received $1 \mathrm{x}$ dose.

\subsection{EB Concentration in Muscle Tissue to Establish} Withdrawal Period. The absorptions of EB reserved in edible tissue (muscle) are presented in Table 2. The EB residue found to be ranged from $0.57 \pm 0.03 \mathrm{ppb}$ to $4.2 \pm 0.03 \mathrm{ppb}$ during the 21-day feeding trial. It was observed that residue was detected in muscle tissue at a very negligible amount which is $0.34 \pm 0.01 \mathrm{ppb}(\mathrm{ng} / \mathrm{g})$ in fish fed with $1 \mathrm{x}$ concentration of $\mathrm{EB}\left(50 \mu \mathrm{g} / \mathrm{kg} \mathrm{b}\right.$. w./day) on $35^{\text {th }}$ day (end of the experiment) and become insignificant $(p>0.05)$ once compared with the initial dose. But fish fed with $2.5 \mathrm{x}, 5 \mathrm{x}$, and $7.5 \mathrm{x}$ concentrations found to be highly significant $(p<0.05)$ level of deposition or retention of EB. It implies that fish fed with higher doses of EB ( $\geq 2.5 \mathrm{x}$ concentration) were unable to defaecate the EB effectively during the 14 days of withdrawal period, and hence, eventually, EB has been deposited significantly $(p<0.05)$ in the muscle tissue.

\section{Discussion}

Parasitic infestation in semi-intensive and intensive aquaculture system is becoming a routine outbreak, to overcome such incidences finding out effective antiparasitic drug is a 


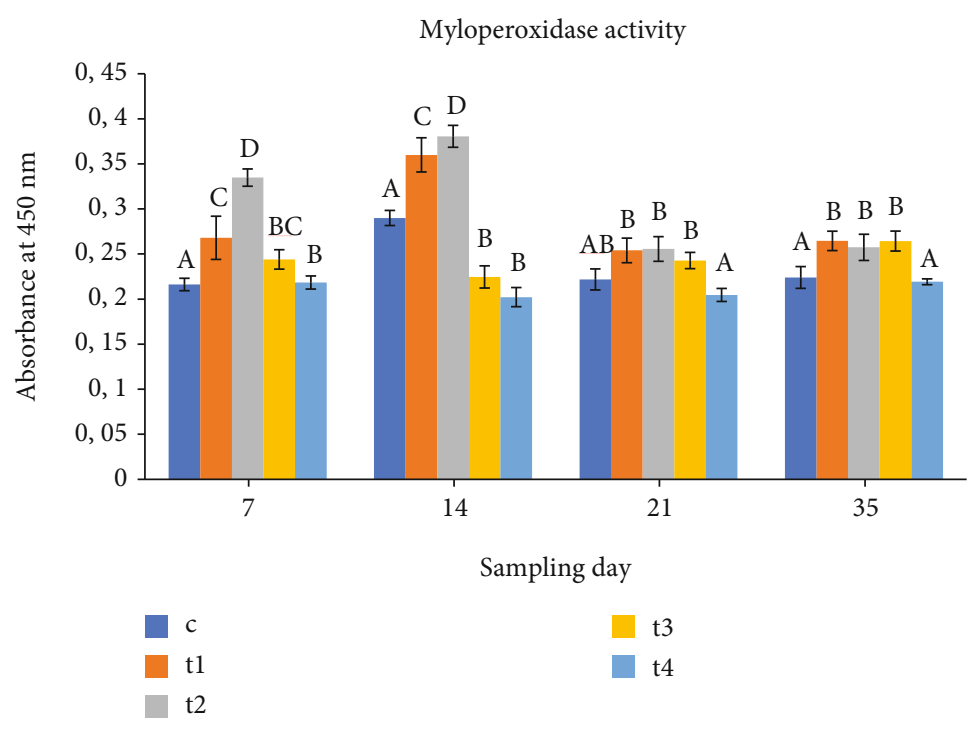

FIGURE 1: Myeloperoxidase activity of Labeo rohita in the control and treated groups at each sampling day. Error bars with different letters $(\mathrm{A}, \mathrm{B}, \mathrm{C}, \mathrm{D})$ indicate significant differences $(P<0.05)$ among groups.

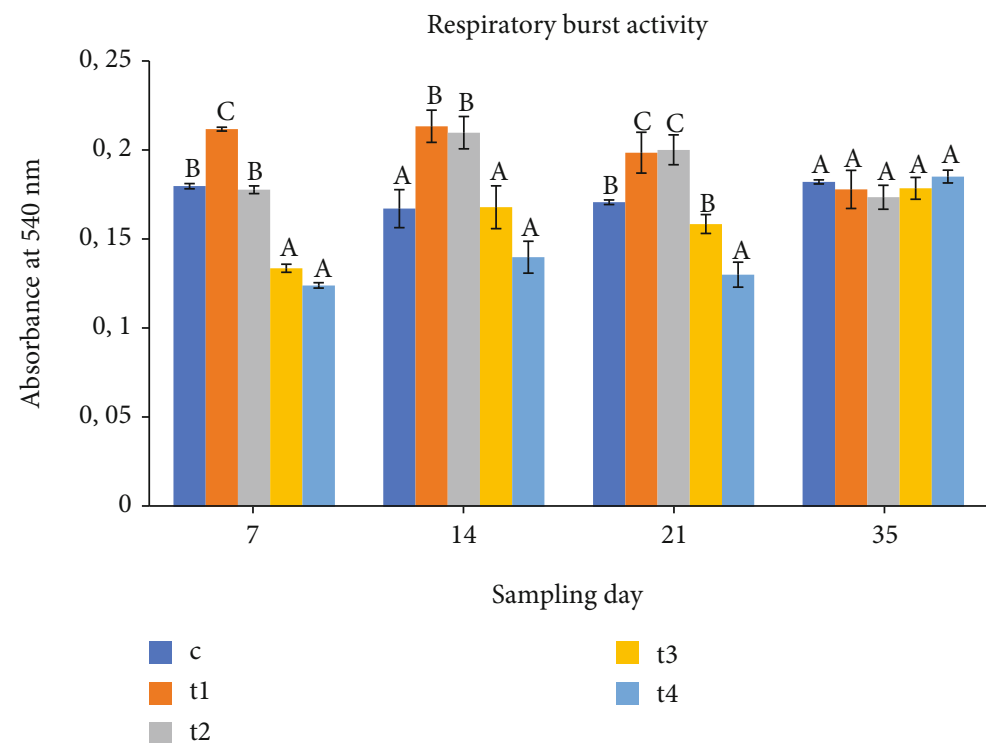

FIGURE 2: Respiratory burst activity of Labeo rohita in the control and treated groups at each sampling day. Error bars with different letters $(\mathrm{A}, \mathrm{B}, \mathrm{C}, \mathrm{D})$ indicate significant differences $(P<0.05)$ among groups.

need-based approach. The use of different chemicals, beyond drugs viz., sodium chloride, formaldehyde, potassium permanganate, formalin, trichlorfon, and powdered quick lime, have been reported by various authors [17-19]. However, in salmon farming, few drugs or chemicals are found to be effective in some extent to control the salmon louse infestation like organophosphates: dichlorvos and azamethiphos; pyrethrine: pyrethrum, cypermethrin, and deltamethrin; an oxidizing agent: oxygen peroxide; three avermectins: ivermectin, EB, and doramectin; and two urea derivatives (benzoyl phenyl ureas): teflubenzuron and diflubenzuron [20]. But, apart from their (drugs) direct therapeutic effects, there might be some additional activities particularly related to immunomodulatory effect on fish host [21]. For example, levamisole has been widely tested in farmed fish with immune stimulating effects, such as enhanced circulating leukocytes, phagocytic, and serum lysozyme activity [22, 23]. Hence, in this study, EB was administered through feed to find out the possible impact on physiological health status of healthy fish (L. rohita) particularly on growth and immune-modulatory effect along with its (EB) level of accumulation or deposition in treated fish muscle tissue.

Growth of farmed fish is always a demanding factor for any aquaculture system, and to attain such demand, farmers or stakeholders are always looking forward to several growth supplements which could be used as regular or alternative 


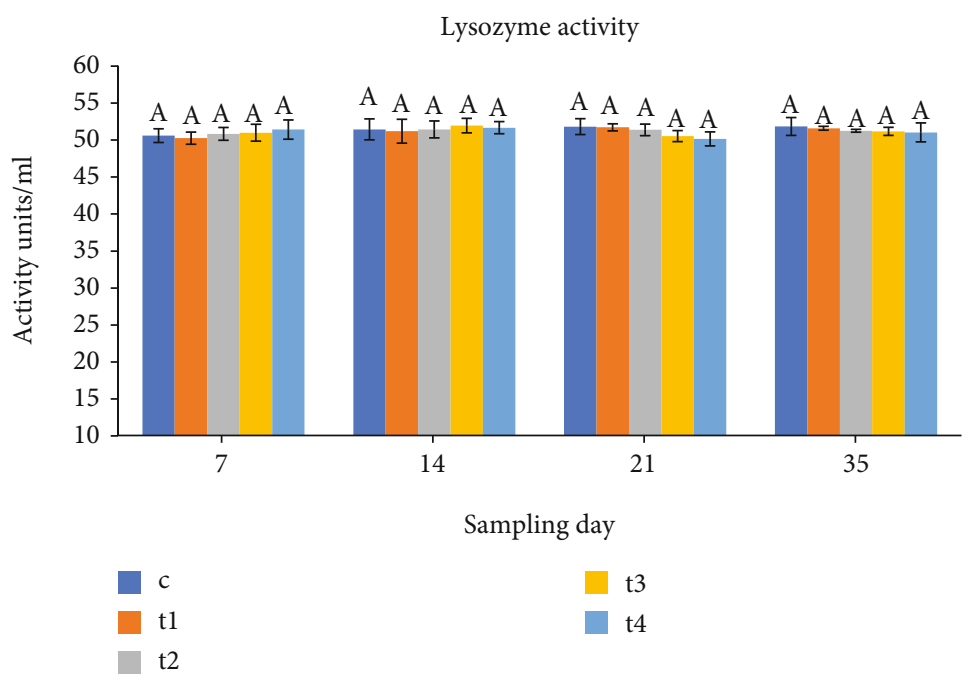

FIGURE 3: Lysozyme activity of Labeo rohita in the control and treated groups at each sampling day. Error bars with different letters (A, B, C, D) indicate significant differences $(P<0.05)$ among groups.

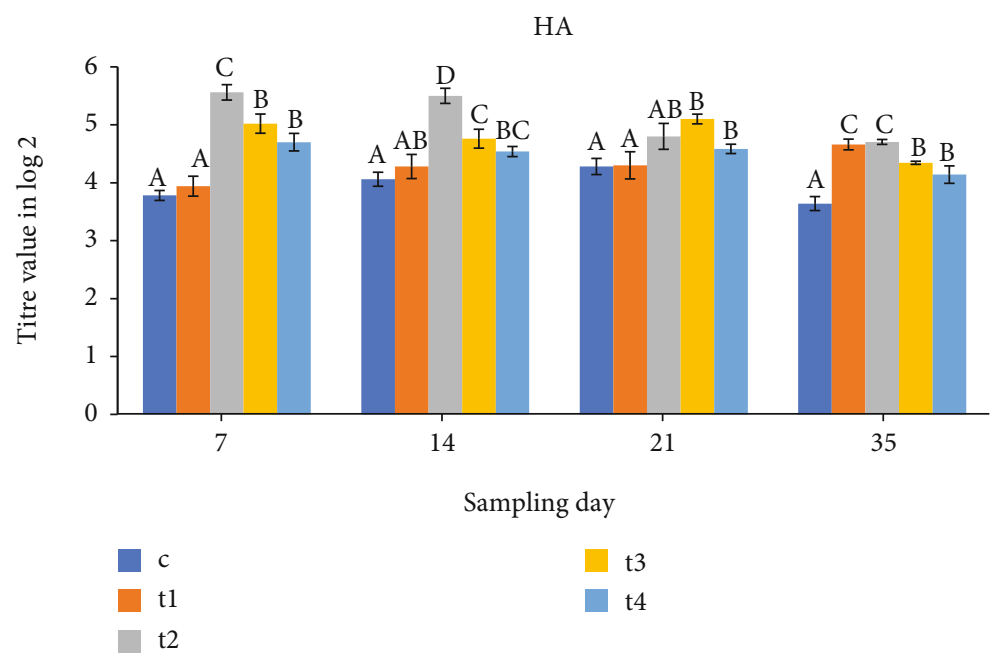

FIGURE 4: Haemaglutination activity of Labeo rohita in the control and treated groups at each sampling day. Error bars with different letters $(\mathrm{A}, \mathrm{B}, \mathrm{C}, \mathrm{D})$ indicate significant differences $(P<0.05)$ among groups.

way as a growth stimulator through feed. In this study, fish were separated as the treatment and control groups and fed with medicated (EB) and control feed for 21 days. Considering the results, the differences between weight gains were not found to be significant $(p>0.05)$ and which is supporting the findings of Kilercioglu et al.[24] where rainbow trout was administered at $50 \mu \mathrm{g} \mathrm{EB} \mathrm{kg}^{-1}$ fish daily for 7,14 , and 21 days. After thorough investigation, we have come to end that no augmentation of growth in EB fed fish groups compared to control fish after 21 days of feeding which corroborate with earlier studies in rainbow trout and Atlantic salmon reported by few distinguished authors [20, 25]. In addition to it, Siavash et al. [26] also found that there was no mortality, or any difference in body weight and length between the controls and treated fish when rainbow trout was treated with another closely related drug i.e., ivermectin at $100 \mu \mathrm{g} \mathrm{kg}^{-1}$ intraperitoneal (IP) injections. However, on the contrary, there is a report or a clinical evidence of toxicity of EB at a high dose of about $272 \mu \mathrm{g} \mathrm{kg}^{-1}$ day $^{-1}$ in which $50 \%$ of fish exhibited dark coloration, and $1 \%$ showed lack of coordinated swimming behaviour [27]. In other studies, it also described similar signs of toxicity in fish treated with the higher dose of other drugs like avermectin and ivermectin $[28,29]$. However, no such effects were noticed in the present study where EB was added in different level (1x$7.5 \mathrm{x})$.

Additionally, in our study, fish appeared to have consumed the medicated feed within 15-30 minutes after it was served. Hence, EB leaching into the water and bounding to bottom organic materials would be negligible or undetectable level. In addition, our experiment was based on an indoor static module where water exchange is done at the rate of $20 \%$ daily. So, organic matter accumulation was not expected. But considering the pond condition, EB might 
BA

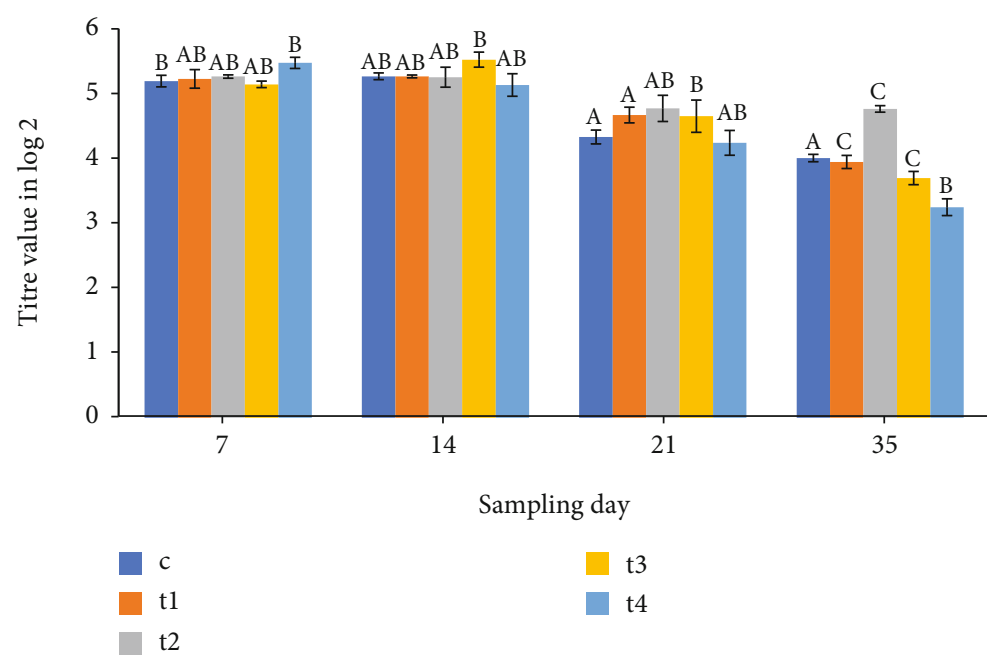

Figure 5: Bacterial agglutination activity of Labeo rohita in the control and treated groups at each sampling day. Different letters (A, B, C, D) indicate significant differences $(P<0.05)$ among groups.

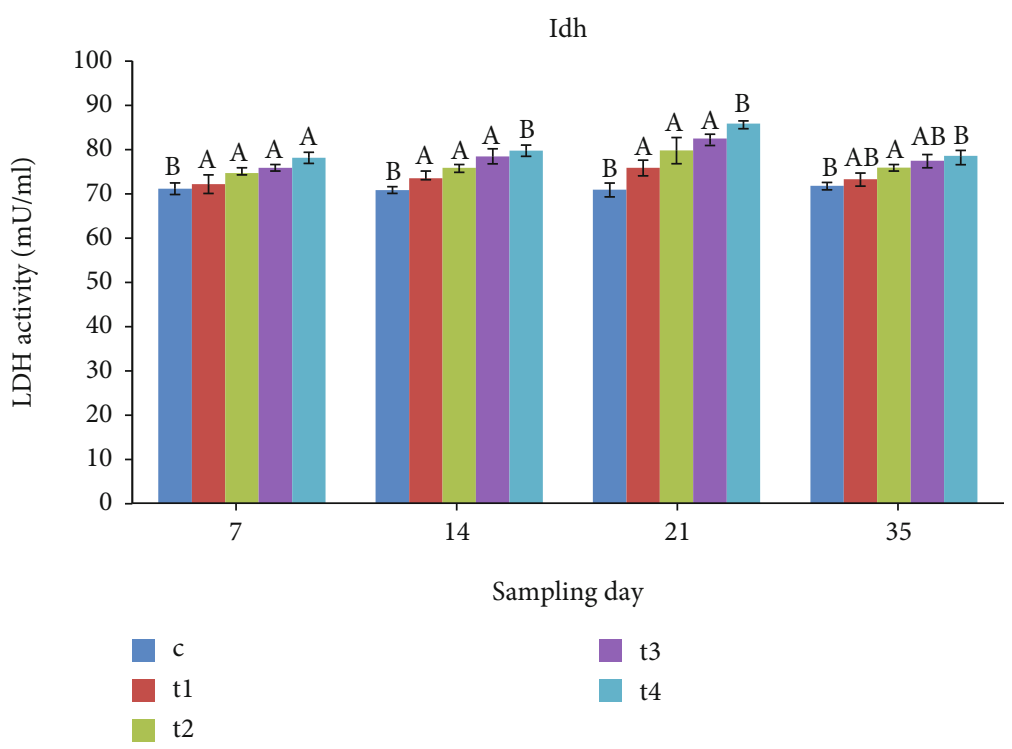

FIGURE 6: Lactate dehydrogenase activity of Labeo rohita in the control and treated groups at each sampling day. Error bars with different letters $(\mathrm{A}, \mathrm{B}, \mathrm{C}, \mathrm{D})$ indicate significant differences $(P<0.05)$ among groups.

get bind with any nontarget species or bottom organic materials as reported in case of teflubenzuron [30] but need further studies to provide constructive views on it. Moreover, $\mathrm{EB}$ is known by the commercial name of Slice ${ }^{\circledR}$ (Fa. Schering-Plough Animal Health, USA) which is approved in Norway and Scotland to combat sea lice infestation of Atlantic salmon with a specific withdrawal period and that active ingredient proved to be efficient in carp lice eradicating in Cyprinus carpio [31], in goldfish and koi carp with infestations of Argulus spp. [32], and in the control of Argulus coregoni in rainbow trout Oncorhynchus mykiss [33]. Further, Braun et al. [31] described dietary treatment with emamectin benzoate $\left(\right.$ Slice ${ }^{\circledR}$ ) was tolerated well in all tested concentration levels and the fish displayed no abnormities in Cyprinus carpio which is in line with our findings.
Immunity acts as a vital element among all animal models including fish, and nonspecific immune parameters plays an important role to fight against wide range of opportunistic pathogens. In freshwater aquaculture farmed fish, majority of the infection is caused by multiple etiological agents or multifactorial in nature. In our present investigation, fish fed with minimum dose ( $1 \mathrm{x}$ and $2.5 \mathrm{x}$ dose) improved respiratory burst activity, myeloperoxidase activit,y and haemolysis. But lysozyme and bacterial haemagglutination remain unchanged as compared to the control group. Experimental fish fed with minimum dose (1x and $2.5 \mathrm{x}$ dose) of EB significantly improved respiratory burst activity, myeloperoxidase activity, bacterial haemagglutination, and haemolysis and lasted for 14 days and become normal after withdrawal of the same on the $35^{\text {th }}$ day. Host 


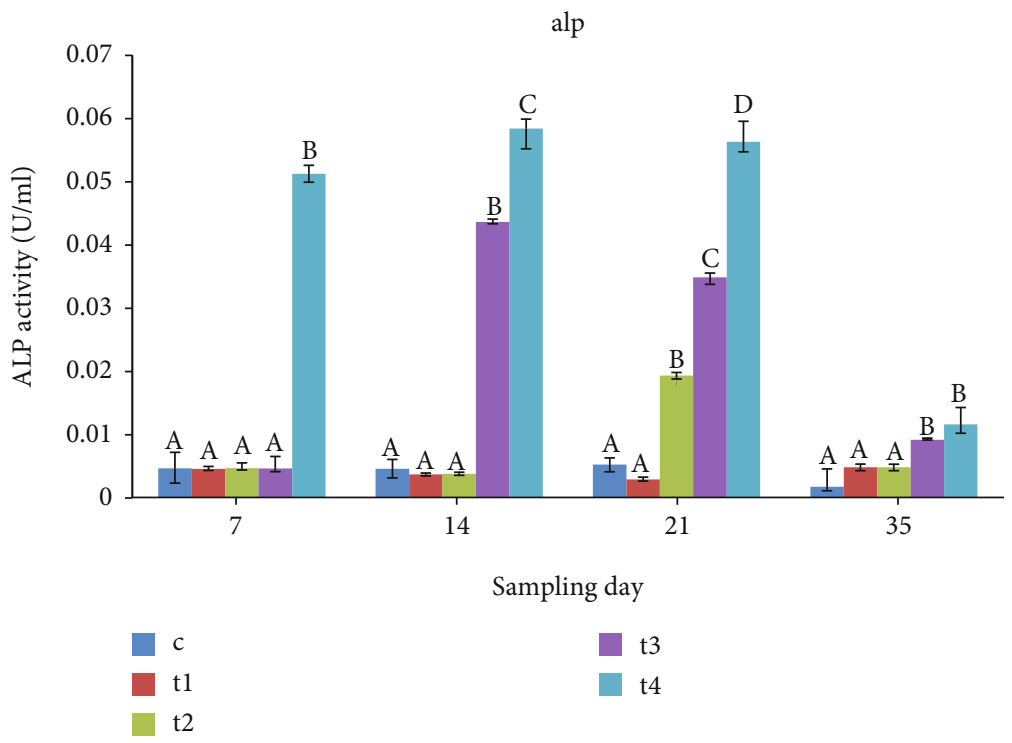

Figure 7: Alkaline phosphatase activity of Labeo rohita in the control and treated groups at each sampling day. Error bars with different letters $(\mathrm{A}, \mathrm{B}, \mathrm{C}, \mathrm{D})$ indicate significant differences $(P<0.05)$ among groups.

TABle 2: EB residue level in muscle tissue (LC-MS/MS study) in different treatment groups during different sampling days (in ppb).

\begin{tabular}{lcccc}
\hline Treatments & $7^{\text {th }}$ day & $14^{\text {th }}$ day & $21^{\text {st }}$ day & $35^{\text {th }}$ day \\
\hline T1 $(1 \mathrm{x}, 50 \mu \mathrm{g} / \mathrm{kg}$ BW/day) & $0.57 \pm 0.03^{\mathrm{a}}$ & $0.65 \pm 0.02^{\mathrm{b}}$ & $0.72 \pm 0.02^{\mathrm{bc}}$ & $0.34 \pm 0.01^{\mathrm{a}}$ \\
T2 $(2.5 \mathrm{x}, 125 \mu \mathrm{g} / \mathrm{kg}$ BW/day) & $0.67 \pm 0.03^{\mathrm{a}}$ & $0.97 \pm 0.07^{\mathrm{b}}$ & $2.2 \pm 0.11^{\mathrm{c}}$ & $0.99 \pm 0.02^{\mathrm{b}}$ \\
T3 $(5 \mathrm{x}, 250 \mu \mathrm{g} / \mathrm{kg}$ BW/day & $0.74 \pm 0.03^{\mathrm{a}}$ & $1.66 \pm 0.03^{\mathrm{b}}$ & $3.1 \pm 0.23^{\mathrm{c}}$ & $1.71 \pm 0.03^{\mathrm{bc}}$ \\
T4 $(7.5 \mathrm{x}, 375 \mu \mathrm{g} / \mathrm{kg} \mathrm{BW} /$ day $)$ & $1.3 \pm 0.03^{\mathrm{a}}$ & $2.3 \pm 0.09^{\mathrm{b}}$ & $4.2 \pm 0.03^{\mathrm{c}}$ & $2.4 \pm 0.09^{\mathrm{bc}}$ \\
\hline
\end{tabular}

Note: all the values are mean \pm standard error (SE) of three determinations. Mean values with different superscripts in the same row are significantly different $(p<0.05)$

immune responses against any supplements might play according to the existing or surrounding water temperature, supplement dose, and route of administration of such component to the host which ultimately effects drug absorption, and for that reason findings of these studies are always species specific $[34,35]$ Furthermore, few studies have indicated that dietary levamisole (drug) could significantly enhance RBT activities in various fish species [36-38]. Likewise, in the present investigation, time course pattern showed that EB also induced elevation of RBT activity in the blood of fish peaked on 14 days of drug postexposure. It has also been reported that immunomodulatory properties of a certain drug significantly influenced by its dosage of inclusion in the fish diet [39]. Siavash et al. [26] also found that single dose of $50 \mu \mathrm{gkg}^{-1}$ intraperitoneal (IP) injections of ivermectin on immunological markers in juvenile rainbow trout Oncorhynchus mykiss induced or elevated phagocytic index (Pi), RBT, along with other immunological parameters like immunoglobulin (Ig), and total plasma protein which are in line with our findings. Hence, it could be explained that EB has limited immunomodulatory effect in the fish but exclusively depends on the dose and route of administration as well as stage of the fish being used. So, it is determined that immune responses in the experiemental fish after fed with $\mathrm{EB}$ depend on the duration of administration, and the dose is given. Additionally, there are not many studies where nonspecific immune parameters of experimental fish have been studied to validate the findings in a more constructive manner, hence in the future while validate the pharmacokinetics or pharmacology study of such antiparasitic drugs the immune related paramters may be incorporated for better explanations.

Serum biochemical parameters mainly hepatic enzymes have been recognized as a valuable tool for monitoring the metabolic and physiological health status of fish after treatment with any chemicals or drugs or supplements [35, 40]. Likewise, in the present investigation, selected hepatic enzymes which deal with stress as well as biomarker for tissue damage have been evaluated in weekly intervals during the administration and also during the withdrawal of the same drug. In this study, enzyme activity mainly LDH and ALP was studied and found to be significantly high in the fish fed with $\mathrm{EB} \geq 250 \mu \mathrm{g} \mathrm{kg}^{-1}$ of fish biomass per day for 21 days. In addition, ALP and LDH mean values were significantly higher ranges compared to the control and fish fed with $1 \mathrm{x}$ dose of EB. Therefore, it might be stated that a higher rate of inclusion of EB pose damage to the important organs like liver cells and ultimately the changes have 
marked in the serum. Furthermore, it is possible to assume that because of detoxification of EB continuously for 21 days, AST/ALP increased in blood/serum [24] which have been observed in our findings also. Similar phenomena regarding enzyme activities in serum have been reported in another antibiotic related study where OTC was fed with basal feed and found to be caused hepatic damages in $L$. rohita [35] and OTC-treated rat [41] to some extent which are in line with our present findings. So, it might be inferring that higher dose of EB has detrimental effect in the internal organs (changes in serum hepatic enzymes); hence, further studies with histopathological intervention should be carried out to make the constructive conclusion on it.

Administration of drugs or antibiotics beyond the recommended dose might lead to antimicrobial residues in the host [42] therefore to figure out safe dose and withdrawal period before administering any drug or antibiotics to the farmed food fishes is highly crucial. Sometimes, the presence of antimicrobial (antibiotics) residues in farmed food fishes may illustrate food safety risks [43]. The calculated elimination half-life from the muscle was found to be similar between the studies with 9.2 days as reported by Sevatdal and his team [44] compared to present results at 7 and 14 days. Skilbrei et al. [45] reported zero or close to zero concentration of EB in Altanic salmon after 63 days of treatment. An adequate margin of safety was revealed in our study at the proposed therapeutic regimen of $50 \mu \mathrm{g} \mathrm{kg}^{-}$ ${ }^{1} \mathrm{BW}^{-1}$ after 14 days withdrawal period. Our study matched with Ananda Raja et al. [14] while studying EB with 10 times the therapeutic dose on Lates calcarifer. Interestingly, OTC [46] and EMB [44] have relatively longer half-life compared to florfenicol [47]. This fact sufficiently explain that during the treatment period faster accumulation of drug happens rather than its elimination. Furthermore, the antiparasitic drugs have a longer half-life period such as EB and are ideal as it offers protection for an extended period, post-treatment, and provide protection during planktonic stages which continue to infect fish even after elimination of the adult crustacean parasites. Disadvantages of using such drug is that it persists for an extended period within the fish at levels below the therapeutic range. This could increase the selection pressure for antimicrobial resistance [48]. In the European Union, the maximum residue limit (MRL) of emamectin in the edible tissue of farmed salmonids has been established which is $100 \mu \mathrm{g} \mathrm{kg}^{-1}$ emamectin B1a [49]. Sevatdal et al. [44] also found that multiple administration of $50 \mu \mathrm{g} \mathrm{kg}^{-1}$ of EB for seven consecutive days has marked a mean concentration of $74.8 \pm 28.4 \mu \mathrm{g} \mathrm{kg}^{-1}$ in the muscle on the last day whilst Skilbrei et al. [45] achieved mean concentrations from 49.4 to $51.9 \mu \mathrm{g} \mathrm{kg}^{-1}$ in three medicated groups of salmon after 7 days post-termination of medication $\left(350 \mu \mathrm{g} \mathrm{kg}^{-1}\right.$ total dosage). So, in this regard, our finding shows that the accumulation in edible muscle tissue is much lower; it might be because we have taken only muscle (no skin part) while studying the EB residue [44]. Further, waning of drug concentrations was steeper than what is reported in salmonids $[29,50,51]$ and might be likely due to the study was conducted in warm water $\left(\sim 30^{\circ} \mathrm{C}\right)$ as $\mathrm{EB}$ residue depletion proceeded more quickly at the higher water tempera- ture [52]. To date, in India, there is no standard or fixed withdrawal period for EB which must be maintained in the aquaculture pond or tank after treating with such antiparasitic drug specifically for the food fishes (carp fishes), so the lowest dose $(1 \mathrm{x})$ which has no detrimental or negative impact on immunity and important serum enzyme activities in the treated fish (L. rohita) may be assumed as a safe dose to carry out the treatment along with 14 days of withdrawal period. Moreover, in this study, 14 days of withdrawal period also resembles that the fish fed with $1 \mathrm{x}$ dose $\left(50 \mu \mathrm{g} \mathrm{kg}^{-1}\right.$ of fish biomass day ${ }^{-1}$ ) has completely discharged the EB from the muscle tissue and final retention of EB was found to be very negligible amount $(0.341 \pm 0.03 \mathrm{ppb})$. Hence, further studies may be carried out in the same line along with histopathological investigation and microbiome of treated fish to establish the standard withdrawal period for approved antiparasitic drugs.

\section{Conclusion}

The antiparasitic drug EB has no harmful effects to rohu, $L$. rohita juveniles while administered at $50 \mu \mathrm{g} \mathrm{kg}^{-1}$ of fish biomass day ${ }^{-1}(1 \mathrm{x}$ dose) through the feed. However, higher doses ( 2.5x dose) of EB fed fish showed significant changes in the important enzyme activities which remain unchanged even after 14 days of withdrawal period. Henceforth, $1 \mathrm{x}$ concentration of EB may be assured to treat the fish against the infection through feed with 14 days of withdrawal period to minimize the $\mathrm{EB}$ residue in muscle (edible) tissue.

\section{Data Availability}

The data used to support the findings of this study are included within the article.

\section{Ethical Approval}

All applicable international, national, and/or institutional guidelines were followed (Institutional Animal Ethics Committee and PME of ICAR-CIFA approval has been taken) for sampling, maintenance, handling, and sacrificing of the fish during experiments.

\section{Conflicts of Interest}

The authors declare that they have no known competing financial interests or personal relationships that could have appeared to influence the work reported in this paper.

\section{Authors' Contributions}

Pushpa Chaudhary did the investigation and writing of the original draft manuscript. Priyabrat Swain did the review of final manuscript and supervision. Rakesh Das did the review and editing of the original draft manuscript constructively, data validation, result interpretations and significantly contributed to the submission of reviewers' queries. Satya Narayan Sahoo did the investigation, formal analysis, and result interpretations. Sudhansu Sekhar Mishra did the visualization, resource acquisition, and supervision. Krushna 
Chandra Das did the feed preparation and feed data analysis. Prasanna Kumar Patil did the overall supervision. All the authors reviewed the manuscript and given consent for submission. Priyabrat Swain and Sudhansu Sekhar Mishra share senior authorship.

\section{Acknowledgments}

The authors wish to express sincere thanks to the Director, ICAR-Central Institute of Freshwater Aquaculture (CIFA), Kausalyaganga, Bhubaneswar, for providing the necessary facilities to carry out the investigation. The authors remain thankful to the Indian Council of Agricultural Research (ICAR), New Delhi, for providing financial support in the form of ICAR-Network project entitled 'All India Network project on Fish Health' (project code: 1007126). Support of Mr. Dillip Kumar Behera, Mr. Dillip Kumar Ojha, and Mr. Biswabhusan Pradhan, Technical Assistants, in sampling is duly acknowledged. The authors are also thankful to ICAR-CIFT, Kochi for rendering all kind of guidance and facility to carry out the LC-MS/MS study and analysis.

\section{References}

[1] M. Akhter, J. Silva, and A. Khatun, "Helminth parasites of Anabas testudineus (Bloch) in Bangladesh," Bangladesh Journal of Zoology, vol. 25, pp. 135-138, 1997.

[2] K. J. Chandra, K. Z. Islam, and R. Wootten, "Some aspects of association and development of Lytocestus indicus moghe in catfish, Clarias batrachus," Bangladesh journal of Fisheries Research, vol. 1, pp. 31-38, 1997.

[3] S. C. Johnson, J. W. Treasurer, S. Bravo, K. Nagasawa, and Z. Kabata, "A review of the impact of parasitic copepods on marine aquaculture,” Zoological Studies, vol. 43, pp. 229-243, 2004.

[4] A. Ramstad, D. J. Colquhoun, R. Nordmo, I. H. Sutherland, and R. D. Simmons, "Field trials in Norway with Slice ${ }^{\circledR}(0.2 \%$ emamectin benzoate) for the oral treatment of sea lice infestation in farmed Atlantic salmon (Salmo salar L.)," Diseases of Aquatic Organisms, vol. 50, pp. 29-33, 2002.

[5] T. Roberts and D. Hutson, "Macrocyclic insecticides," in Metabolic Pathways of Agrochemicals: Part 2: Insecticides and Fungicides, T. Roberts and D. Hutson, Eds., pp. 87-94, The Royal Society of Chemistry, Cambridge, U. K, 1999.

[6] G. L. Leibee, R. K. Jansson, G. Nuessly, and J. L. Taylor, "Efficacy of emamectin benzoate and Bacillus thuringensis at controlling diamond back moth (Lepidoptera: Plutellidae) populations on cabbage in Florida," Florida Entomologist, vol. 78, pp. 82-96, 1995.

[7] R. B. Julinta, T. J. Abraham, A. Roy et al., "Safety of emamectin benzoate administered in feed to Nile tilapia Oreochromis niloticus (L.)," Environmental Toxicology and Pharmacology, vol. 75, article 103348, 2020.

[8] APHA, Standard Methods for the Examination of Water and Wastewater, Washington, DC, 2012.

[9] M. J. Quade and J. A. Roth, "A rapid, direct assay to measure degranulation of bovine neutrophil primary granules," Veterinary Immunology and Immunopathology, vol. 58, pp. 239-248, 1997.

[10] D. P. Anderson and A. K. Siwicki, "Duration of protection against Aeromonas salmonicida in brook trout immunostimu- lated with glucan or chitosan by injection or immersion," The Progressive Fish-Culturist, vol. 56, pp. 258-261, 1994.

[11] A. E. Ellis, "Lysozyme assays," in Techniques in fish immunology, J. S. Stolen, T. C. Fletcher, D. P. Anderson, B. S. Roberson, and W. B. Van Muiswinkel, Eds., pp. 101-103, SOS Publications, Fair Haven, USA, 1990.

[12] P. Swain, R. Das, A. Das, S. K. Padhi, K. C. Das, and S. S. Mishra, "Effects of dietary zinc oxide and selenium nanoparticles on growth performance, immune responses and enzyme activity in rohu, Labeo rohita (Hamilton)," Aquaculture Nutrition, vol. 25, pp. 486-494, 2019.

[13] V. S. Blazer and R. E. Wolke, "The effects of $\alpha$-tocopherol on the immune response and non-specific resistance factors of rainbow trout (Salmo gairdneri Richardson)," Aquaculture, vol. 37, pp. 1-9, 1984.

[14] R. Ananda Raja, P. K. Patil, S. Avunje, P. R. Aravind, S. V. Alavandi, and K. K. Vijayan, "Biosafety, withdrawal and efficacy of anti-parasitic drug emamectin benzoate in Asian seabass (Lates calcarifer)," Aquaculture, vol. 525, article 735335, 2020.

[15] J. H. Zar, Biostatistical Analysis, Prentice Hall, Upper Saddle River, NJ, 4th edition, 1999.

[16] R. G. D. Steel and J. H. Torrie, Principles and Procedures of Statistics, McGraw-Hill, New York, second edition, 1980.

[17] S. Kumar, S. T. Kumar, R. Vidya, and P. K. Pandey, "A prospective of epidemiological intervention in investigation and management of argulosis in aquaculture," Aquaculture International, vol. 25, pp. 303-325, 2016.

[18] R. N. Singhal, S. Jeet, and R. W. Davies, "Chemotherapy of six ectoparasitic diseases of cultured fish," Aquaculture, vol. 54, pp. 165-171, 1986.

[19] W. H. Wildgoose and G. A. Lewbart, "Therapeutics," in Manual of Ornamental Fish, W. H. Wildgoose, Ed., no. 2pp. 237-258, British Small Animal Veterinary Association, Gloucester, UK, 2001.

[20] W. J. Roy, I. H. Sutherland, H. D. M. Rodger, and K. J. Varma, "Tolerance of Atlantic salmon, Salmo salar L., and rainbow trout, Oncorhynchus mykiss (Walbaum) to emamectin benzoate, a new orally administered treatment for sea lice," Aquaculture, vol. 184, pp. 19-29, 2000.

[21] M. S. Sajid, Z. Iqbal, G. Muhammad, and M. U. Iqbal, "Immunomodulatory effect of various anti-parasitics: a review," Parasitology, vol. 132, pp. 301-313, 2006.

[22] A. Gopalakannan and V. Arul, "Immunomodulatory effects of chitin, chitosan and levamisole on the immune system of Cyprinus carpio and control of Aeromonas hydrophila infection in ponds," Aquaculture, vol. 255, pp. 179-187, 2006.

[23] G. Li, Y. Guo, D. Zhao et al., "Effects of levamisole on the immune response and disease resistance of Clarias fuscus," Aquaculture, vol. 253, pp. 212-217, 2006.

[24] S. Kilercioglu, O. Ay, H. Oksuz, and M. B. Yilmaz, "The effects of the neurotoxic agent emamectin benzoate on the expression of immune and stress-related genes and blood serum profiles in the rainbow trout," Molecular Biology Reports, vol. 47, pp. 5243-5251, 2020.

[25] J. D. Bowker, D. Carty, and M. P. Bowman, "The safety of SLICE ( $0.2 \%$ emamectin benzoate) administered in feed to fingerling rainbow trout," North American Journal of Aquaculture, vol. 75, pp. 455-462, 2013.

[26] S. Siavash, A. M. Nabi, and G. Nastara, "Effect of Ivermectin on blood and immunological markers in rainbow trout 
(Oncorhynchus mykiss)," OJVR Online Journal of Veterinary Research, vol. 18, pp. 612-622, 2014.

[27] J. Stone, I. H. Sutherland, C. Sommerville, R. H. Richards, and K. J. Varma, "The efficacy of emamectin benzoate as an oral treatment of sea lice, Lepeophtheirus salmonis (Kroyer), infestations in Atlantic salmon," Journal of Fish Diseases, vol. 22, pp. 261-270, 1999.

[28] S. C. Johnson and L. Margolis, "Efficacy of ivermectin for control of the salmon louse, Lepeophtheirus salmonis, on Atlantic salmon," Diseases of Aquatic Organisms, vol. 17, pp. 101-105, 1993, https://www.int-res.com/articles/dao/17/d017p101.pdf.

[29] R. Palmer, R. Coyne, S. Davey, and P. Smith, "Case notes on adverse reactions associated with ivermectin therapy of Atlantic salmon," Bulletin- European Association of Fish Pathologists, vol. 17, pp. 62-67, 1997, http://agris.fao.org/agrissearch/search.do?recordID=GB9718941.

[30] O. B. Samuelsen, B. T. Lunestad, R. Hannisdal et al., "Distribution and persistence of the anti sea-lice drug teflubenzuron in wild fauna and sediments around a Salmon farm, a standard treatment," Science of the Total Environment, vol. 508, pp. 115-121, 2015.

[31] E. Braun, O. Hochwartner, A. Tichy, A. Joachim, and E. Licek, "Safety and efficacy of antiparasitic drugs for treatment of salmonids in breeding carp (Cyprinus carpiomorpha domestica)," Wiener Tierarztliche Monatsschrift, vol. 95, pp. 210-218, 2008.

[32] S. K. Hanson, J. E. Hill, C. A. Watson, R. P. E. Yanong, and R. Endris, "Evaluation of emamectin benzoate for the control of experimentally induced infestations of Argulus sp. in goldfish and koi carp," Journal of Aquatic Animal Health, vol. 23, pp. 30-34, 2011.

[33] T. Hakalahti, Y. Lankinen, and E. T. Valtonen, "Efficacy of emamectin benzoate in the control of Argulus coregoni (Crustacea: Branchiura) on rainbow trout Oncorhynchus mykiss," Diseases of Aquatic Organism, vol. 60, pp. 197-204, 2004.

[34] H. Bjorklund and G. Bylund, "Temperature-related absorption and excretion of oxytetracycline in rainbow trout (Salmo gairdneri R.)," Aquaculture, vol. 84, pp. 363-372, 1990.

[35] R. Das, P. Swain, S. N. Sahoo et al., "Evaluation of oxytetracycline hydrochloride (OTC) on non-specific immunity, enzymatic profiles and tissue level retention in Labeo rohita (Hamilton, 1822) after administration through feed," Aquaculture Research, vol. 52, pp. 3301-3309, 2021.

[36] U. Ispir and M. Dorucu, "A study on the effects of levamisole on the immune system of rainbow trout (Oncorhynchus mykiss, Walbaum)," Turkish Journal of Veterinary and Animal Sciences, vol. 29, pp. 1169-1176, 2005.

[37] S. Maqsood, M. H. Samoon, and P. Singh, "Immunomodulatory and growth promoting effect of dietary levamisole in Cyprinus carpio fingerlings against the challenge of Aeromonas hydrophila," Turkish Journal of Fisheries and Aquatic Sciences, vol. 9, pp. 111-120, 2009.

[38] E. Seker, U. Ispir, and M. Dorucu, "Immunostimulating effect of levamisole on spleen and head kidney leucocytes of rainbow trout (Oncorhynchus mykiss; Walbaum 1792)," Kafkas Universitesi Veteriner Fakultesi Dergisi, vol. 17, pp. 239-242, 2011.

[39] R. M. Jaafar, J. Skov, P. W. Kania, and K. Buchmann, “Dose dependent effects of dietary immunostimulants on rainbow trout immune parameters and susceptibility to the parasite Ichthyophthirius multifiliis," Journal of Aquaculture Research and Development, vol. 3, p. 1, 2011.
[40] A. H. Mondal, T. Behera, P. Swain et al., "Nano zinc vis-à-vis inorganic zinc as feed additives: effects on growth, activity of hepatic enzymes and non-specific immunity in rohu," Aquaculture Nutrition, vol. 26, pp. 1211-1222, 2020.

[41] L. Pari and M. Gnanasoundari, "Influence of naringenin on oxytetracycline mediated oxidative damage in rat liver," Basic \& Clinical Pharmacology \& Toxicology, vol. 98, pp. 456-461, 2006.

[42] R. L. Butt and H. Volkoff, "Gut microbiota and energy homeostasis in fish," Frontiers in Endocrinology, vol. 10, article 9, 2019.

[43] K. Li, L. Liu, J. Zhan et al., "Sources and fate of antimicrobials in integrated fish-pig and non-integrated tilapia farms," Science of the Total Environment, vol. 595, pp. 393-399, 2017.

[44] S. Sevatdal, A. Magnusson, K. Ingebrigtsen, R. Haldorsen, and T. E. Horsberg, "Distribution of emamectin benzoate in Atlantic Salmon (Salmo salar L.)," Journal of Veterinary Pharmacology and Therapeutics, vol. 28, pp. 101-107, 2005.

[45] O. T. Skilbrei, K. A. Glover, O. B. Samuelsen, and B. T. Lunestad, "A laboratory study to evaluate the use of emamectin benzoate in the control of sea lice in sea-ranched Atlantic Salmon (Salmo salar L.)," Aquaculture, vol. 285, pp. 2-7, 2008.

[46] M. Elema, K. Hoff, and H. Kristensen, "Bioavailability of oxytetracycline from medicated feed administered to Atlantic salmon (Salmo salar L.) in seawater," Aquaculture, vol. 143, pp. 7-14, 1996.

[47] B. Martinsen, T. E. Horsberg, K. Varma, and R. Sams, "Single dose pharmacokinetic study of florfenicol in Atlantic salmon (Salmo salar) in seawater at 11C," Aquaculture, vol. 112, pp. 1-11, 1993.

[48] J. Davies and D. Davies, "Origins and evolution of antibiotic resistance," Microbiology and Molecular Biology Reviews, vol. 74, pp. 417-433, 2010.

[49] EMEA, "Committee for Veterinary Medicinal Products. Summary report: Emamectin (1)," 2003, Report no. EMEA/MRL/ 546/99-FINAL https://www.ema.europa.eu/en/committees/ committee-medicinal-products-veterinary-use-cvmp.

[50] S. M. Limbu, L. Zhou, S.-X. Sun, M. L. Zhang, and Z. Y. Du, "Chronic exposure to low environmental concentrations and legal aquaculture doses of antibiotics cause systemic adverse effects in Nile tilapia and provoke differential human health risk," Environment International, vol. 115, pp. 205-219, 2018.

[51] J. T. Trushenski, M. P. Aardsma, K. J. Barry et al., "Oxytetracycline does not cause growth promotion in finfish," Indian Journal of Animal Sciences, vol. 96, pp. 1667-1677, 2018.

[52] W. J. Roy, N. Gillan, L. Crouch, R. Parke, H. Rodger, and R. Endris, "Depletion of emamectin residues following oral administration to rainbow trout, Oncorhynchus mykiss," Aquaculture, vol. 259, pp. 6-16, 2006. 